\title{
DEVELOPMENT AND VALIDATION OF THE METHOD FOR SIMULTANEOUS DETERMINATION OF BENZYDAMINE HYDROCHLORIDE AND METHYLPARABEN IN DOSAGE FORM BY HPLC
}

\author{
V. Chornyi, V. Georgiyants, O. Chorna
}

\begin{abstract}
Мета дослідження. Метою даної роботи було розробити та затвердити метод ВЕРХ для одночасного визначення бензидаміну гідрохлориду (АФI) та метилпарабену (консервант) у лікарській формі, щзо містить бензидамін гідрохлорид як активний фармацевтичний інгредієнт.

Методи. Розділення проводили на колонці Grace Altima C18 (250*4,6 мм, розмір частинок 5 мкм). Рухома фаза складалася з 3,0 г перхлорату натрію, 1 мл триметиламіну і доводилася до рН 3 перхлорною кислотою. Швидкість потоку рухомої фази становила 1 мл / хв, довжина хвилі виявлення - 320 нм для гідрохлориду бензидаміну та 254 нм для метилпарабену.
\end{abstract}

Результати. Метод був перевірений відповідно до вимог ICH Q2 і визнаний надійним, специфічним, лінійним в діапазоні від $80 \%$ до $120 \%$ для аналізованої речовини. Максимальне RSD для кожного з'єднання становило менше $1.3 \%$. Точність методу була в межах критерїв прийнятності.

Висновки. Метод одночасного визначення бензидаміну гідрохлориду та метилпарабену був розроблений i затверджений відповідно до вимог Міжнародної конференції з гармонізації. Всі параметри валідаџіi відповідають критеріям прийнятності керівництва.

Розроблений метод може бути застосований в рутинному контролі в лабораторіях контролю якості для одночасного визначення бензидаміну гідрохлориду та метилпарабену в лікарських формах бензидаміну.

Ключові слова: ВЕРХ, бензидамін гідрохлорид, метилпарабен, валідачія методу, одночасне визначення.

Copyright (C) 2020, V. Chornyi, V. Georgiyants, O. Chorna. This is an open access article under the CC BY license (http://creativecommons.org/licenses/by/4.0).

\section{Introduction}

Benzydamine hydrochloride is a nonsteroidal, anti-inflammatory drug with local anesthetic and analgesic properties for pain relief, mouth and throat inflammations treatment [1]. On the Ukrainian market, Benzydamine hydrochloride is presented in drug products Tantum Verde, Oralsept, and Tantum Rosa. Benzydamine hydrochloride quality requirements are given in the British Pharmacopoeia [2].

In routine drug analysis, quality requirements for analytical methods, e.g. high precision and short time of analysis, imply optimization and universalization of techniques that allow determining several compounds with one injection. Therefore, we analyzed the possibility of simultaneous determination of the active substance Benzydamine hydrochloride and the excipient Methylparaben in a single sample.

The British Pharmacopoeia describes Benzydamine hydrochloride quantitative determination by gas chromatography [3], with chloroform extraction using a non-polar phase (OV-17). In this case, simultaneous quantification of Benzydamine hydrochloride and methylparaben looks rather problematic due to prolonged and complicated sample preparation and related uncertainty of the final procedure.

There are a number of articles describing the quantitative determination of Benzydamine hydrochloride in the finished dosage forms by HPLC [4-6]. Separation of Benzydamine is described with utilization of RP-phase with fluorescence or spectrophotometric detec- tion in either finished dosage forms or blood samples. Separation was recommended to be performed on Nucleosil-100 C18 phase with thriethylamine phosphate buffer ( $\mathrm{pH} 3.0)$ and acetonitrile (35-65 v/v). Such approach is implemented also because the HPLC mode of separation is the most efficient for the complex mixtures.

Separation of methylparaben in the dosage forms is also preferable with RP-HPLC especially in combinations with other active substances or preservatives [7-9]. Agilent Zorbax C18 column is reported to be effective in tandem with buffer- acetonitrile solution (80-20 v/v). Another separation of parabens mixture was reported to be done on Lichrosorbe C8 stationary phase and isocratic elution with tetrahydrofurane-acetonitrile-water isocratic elution and spectrophotometric detection. However, from the literature review, the simultaneous determination of these compounds in dosage forms is not described to date.

\section{Planning (methodology) of the research}

According to contemporary issues of "Green Chemistry", simultaneous determination of analytes in one sample is a high priority for analytical chemists [10-12]. Therefore, the primary method development strategy should be based on the thorough assessment of the possibility of time and resource minimization $[13,14]$.

Thus, the development of the analytical method for simultaneous quantification of Benzydamine hydrochloride and Methylparaben in the dosage form is relevant in terms of minimizing costs, resources, time, and 
reagents. Our task was to develop the appropriate method and to prove its validity according to ICH Q2 European regulatory requirements $[15,16]$.

\section{Materials and methods}

Sigma Aldrich (Germany) supplied Acetonitrile (HPLC grade). Sodium perchlorate and perchloric acid were purchased from Fluka Chemika Bio Chemika (Buchs, Switzerland).

Benzydamine hydrochloride reference standard was purchased as the Brittish Pharmacopoeia standard. Sigma Aldrich (Germany) supplied Methylparaben reference standard.

Water (HPLC grade) was obtained from a Milli-Q plot water purification system (MA, USA) and was used for the preparation of mobile phase buffers and reagent solutions.

Apparatus and software

Chromatography was carried out using Shimadzu LC-20 liquid chromatograph with a diode array detector, autosampler, degasser, and quaternary pump. LC Solution software was used for data acquisition.

Chromatographic conditions

Grace Altima C18 column $(250 * 4.6 \mathrm{~mm}$, particle size $5 \mu \mathrm{m}$ ) was used for the analyte separation. The mobile phase was prepared as follows: $3.0 \mathrm{~g}$ of sodium perchlorate was dissolved in $500 \mathrm{ml}$ of water, then $1.0 \mathrm{ml}$ of triethylamine was added, $\mathrm{pH}$ was adjusted to 3.0 with perchloric acid, and finally, $500 \mathrm{ml}$ of acetonitrile were added. The flow rate was $1 \mathrm{ml} / \mathrm{min}$, wavelength $320 \mathrm{~nm}$; ambient column temperature.

Chromatography was carried out using $20 \mu \mathrm{l}$ of both reference and test solutions.

\section{Results}

Development of analytical HPLC procedure is a problem, a solution of which implies the selection of chromatographic conditions, detection wavelength, mobile phase flow rate, mobile and stationary phase composition. Selection of these conditions depends on the physical and chemical properties of analytes [17].

Chemical structure of Benzydamine hydrochloride (Fig. 1) is N, N-dimethyl-3-[[1-(phenylmethyl)-1Hindazol-3-yl] oxy]-1-propanamine (as hydrochloride), i.e. it is a salt formed with a weak base and a strong acid; methylparaben (Fig. 2) is a methyl ester of parahydroxybenzoic acid.

Ionization constants for Benzydamine hydrochloride and methylparaben are 9.33 and 8.5 respectively [18, 19]. Based on this, Benzydamine hydrochloride is protonated at $\mathrm{pH} 7.2$ and less, and deprotonated - at $\mathrm{pH} 11.4$ and higher. Methylparaben is protonated at $\mathrm{pH} 6.5$ and less, and deprotonated - at pH 10.5 and higher.

From the theory of chromatography, it is known that for satisfactory retention of the analyte on the stationary phase, it should be in a neutral not ionized state [20]. However, Benzydamine hydrochloride exists in a molecular state only at pH 10 and higher. The utilization of a mobile phase with the mentioned $\mathrm{pH}$ value is not applicable for most chromatographic columns, as it leads to irreversible degradation of the stationary phase.

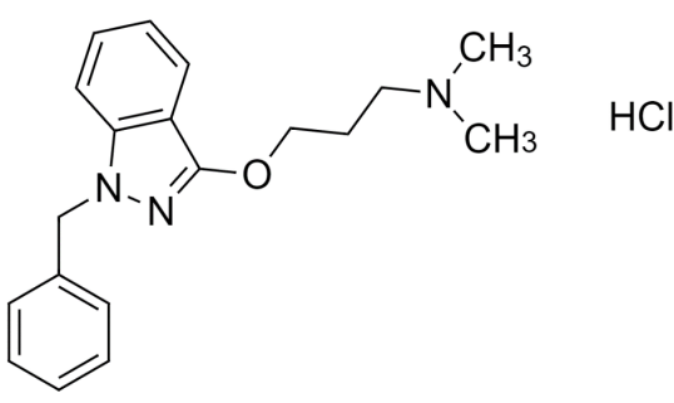

Fig. 1. Structure of Benzydamine hydrochloride

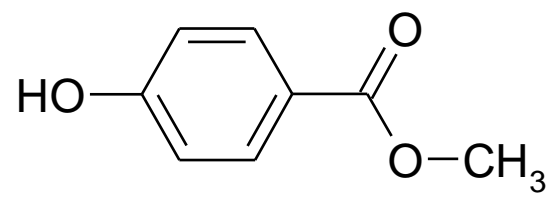

Fig. 2. Structure of methylparaben

In practice, chromatographic buffers with the $\mathrm{pH}$ range 2-8 are used most commonly. At this $\mathrm{pH}$ range, Benzydamine hydrochloride will be protonated and methylparaben will stay neutral.

For the method development, we used solutions of sodium perchlorate buffer at $\mathrm{pH} \mathrm{3,4}$ and 5. Stationary phases $\mathrm{C} 8$ and $\mathrm{C} 18$ were varied for selection of the best performance. The best results were obtained on the C18 sorbent phase at $\mathrm{pH}$ 3.0. Under the mentioned conditions, the effectiveness of the chromatographic system was 8700 theoretical plates for Benzydamine peak.

The detection wavelength was determined from the results of the analysis of Benzydamine hydrochloride and methylparaben absorption spectra. The wavelengths of $320 \mathrm{~nm}$ for Benzydamine hydrochloride and $254 \mathrm{~nm}$ for methylparaben were selected in accordance with the absorption maximums of the analytes (Fig. 3, 4).

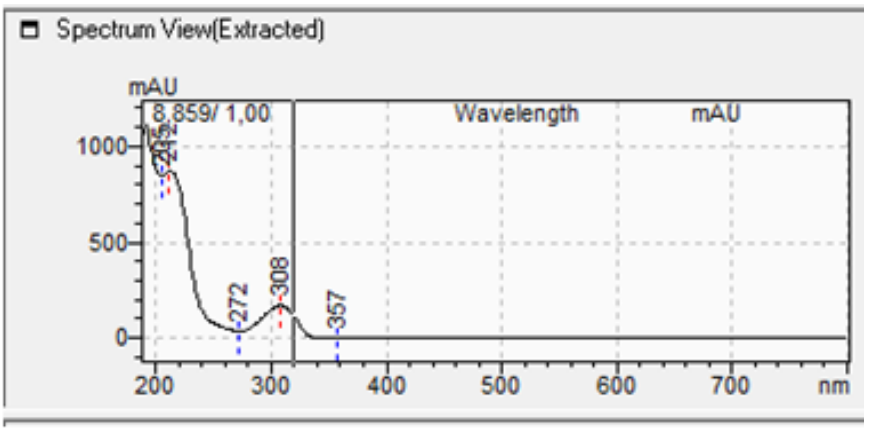

Fig. 3. Absorption spectra of Benzydamine

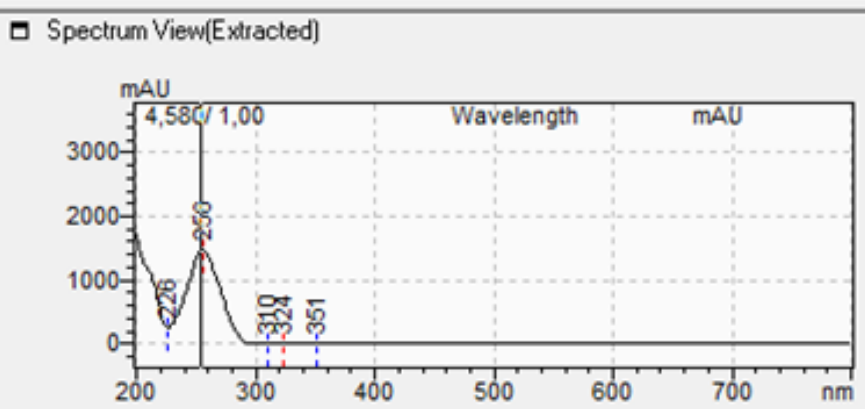

Fig. 4. Absorption spectra of methylparaben 
For separation optimization, the ratio of acetonitrile was varied. The best separation was achieved at a ratio of $1: 1$.

The symmetry of the peaks varied by the modifier triethylamine.

\section{Validation of the HPLC Method}

The developed HPLC method was validated in accordance with the ICH Q2 requirements [12]. The method was tested for linearity, precision, accuracy, robustness, and specificity.

\section{Specificity}

The mobile phase, solvent, placebo solution, placebo model solution 1 and placebo model solution 2, a reference solution and test solution were injected under the method conditions. The specificity of the method was demonstrated by the absence of interference between the analytes of the dosage form.

In the chromatograms of the test solution, no interference between peaks of analyzed components was observed. Consequently, the method is specific to the defined analytes (Fig. 5, 6).

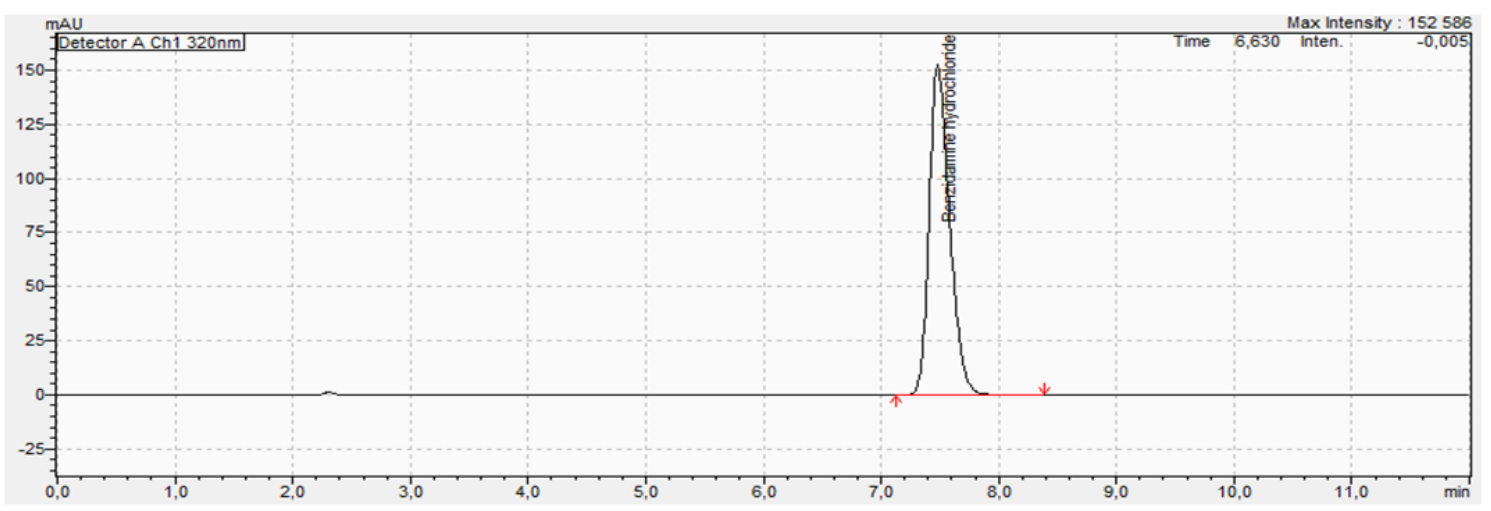

Fig. 5. The chromatogram of test solution at $320 \mathrm{~nm}$

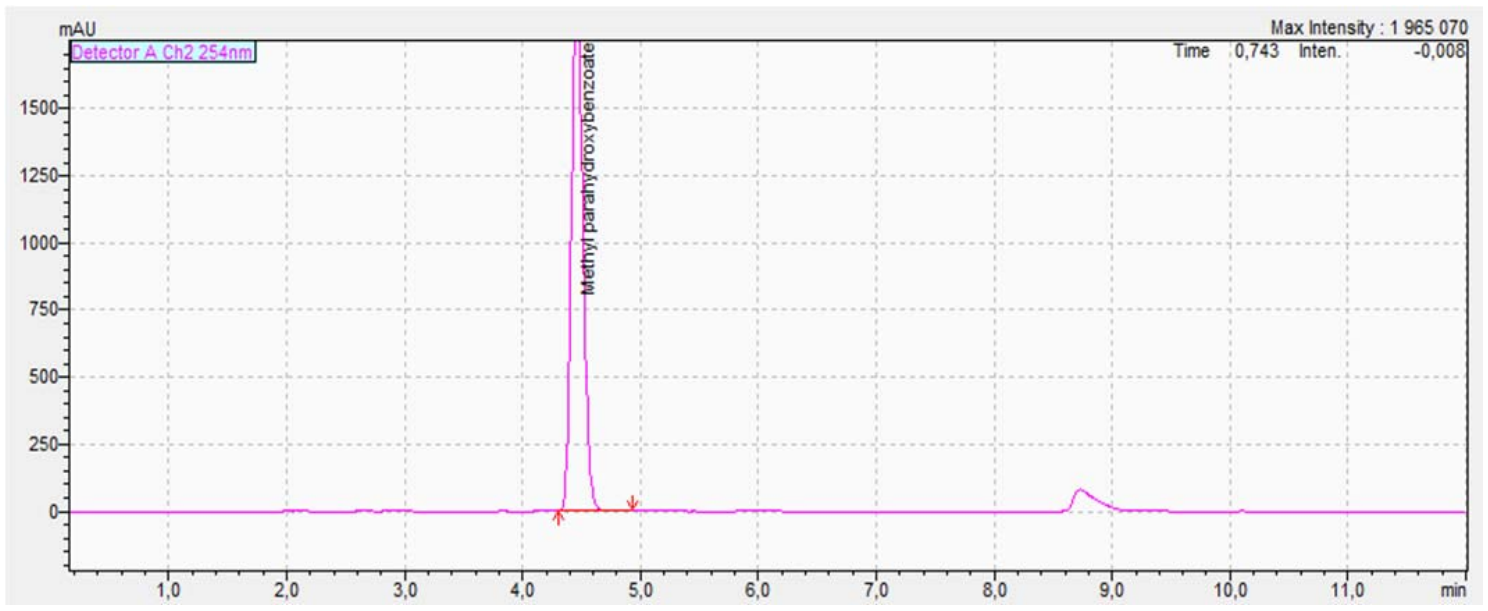

Fig. 6. The chromatogram of test solution at $254 \mathrm{~nm}$

\section{Linearity}

Linearity for Benzydamine hydrochloride and methylparaben was studied in the concentration range of $80-120 \%$ relative to the concentration of corresponding analytes in the reference solution (Fig. 7, 8).
For each of the analytes, five model solutions were prepared and chromatographed under method conditions. The data obtained for Benzydamine hydrochloride are given in Table 1. Methylparaben data obtained are indicated in Table 2. 
Linearity of Assay Test of Benzydamine hydrochloride in "Benzydamine, spray 1.5 $\mathrm{mg} / \mathrm{ml} "$

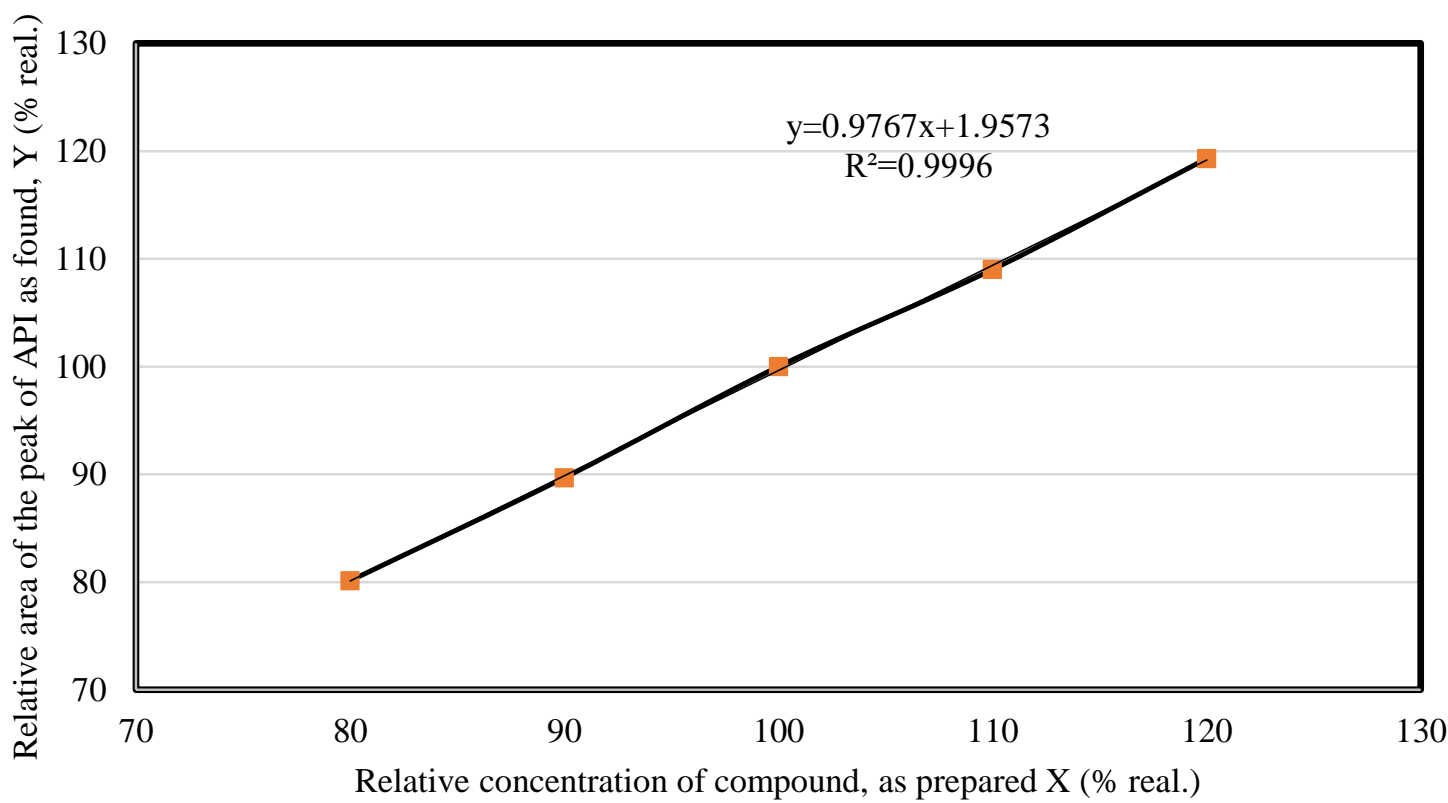

Fig. 7. Graph of determined Benzydamine hydrochloride content versus theoretical content

Linearity of Assay Test of Methylparaben in "Benzydamine, spray 1,5 mg/ml"

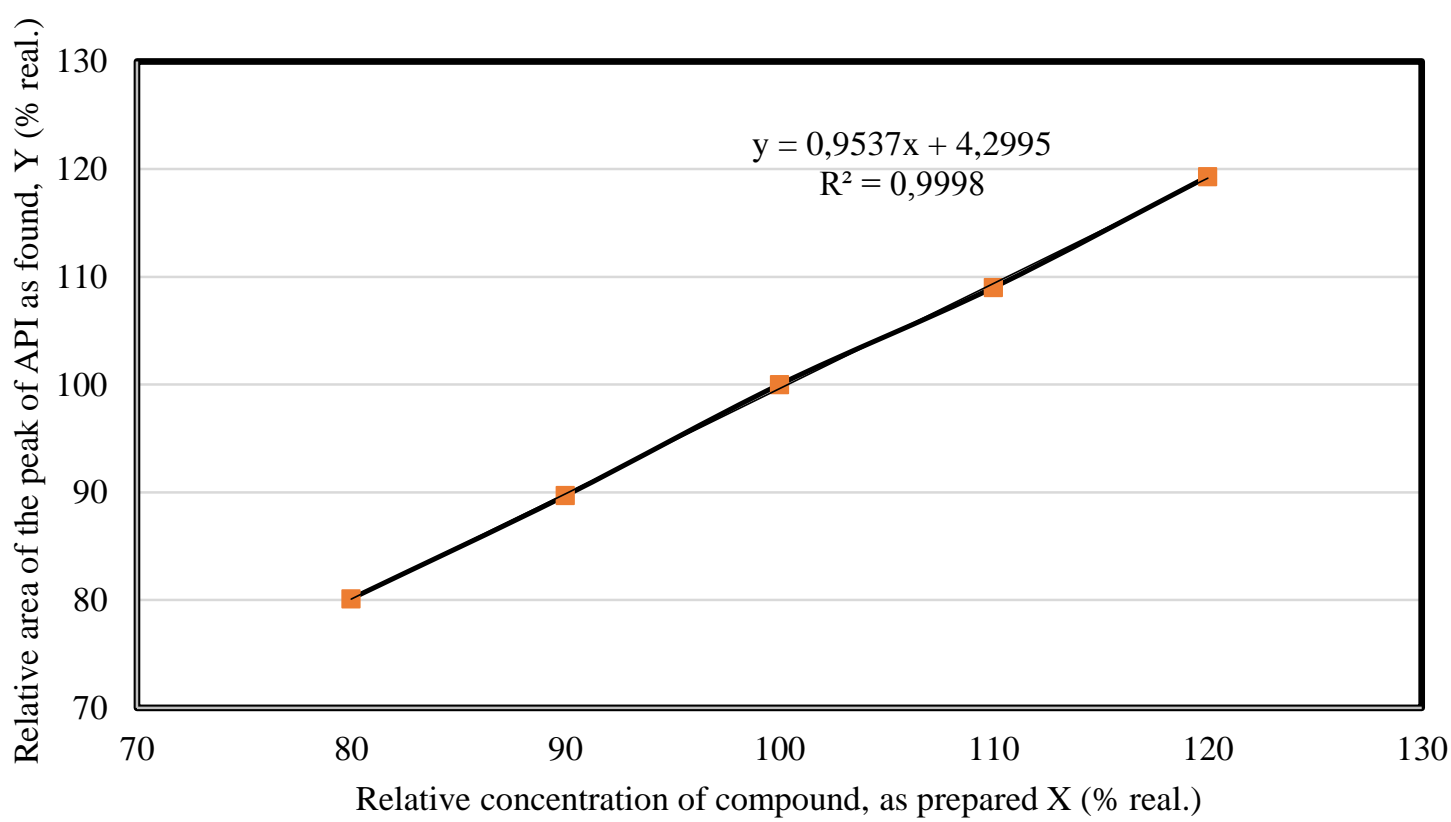

Fig. 8. Graph of determined methylparaben content versus theoretical content

Table 1

Estimated data for linearity of Benzydamine hydrochloride

\begin{tabular}{|c|c|c|c|c|} 
Number of solution & $\mathrm{Ci}, \mathrm{mg} / \mathrm{ml}$ & $\mathrm{Ci}, \%$ (theoretical) & $\mathrm{Si} / \mathrm{S} * 100 \%, \%$ (found) & $\mathrm{RRF}$ \\
\hline 1 & 0.1208 & 80.00 & $80.13 \pm 0.48$ & 100.16 \\
2 & 0.1359 & 90.00 & $89.69 \pm 0.39$ & 99.65 \\
\hline 3 & 0.1510 & 100.00 & $100.00 \pm 0.26$ & 100.00 \\
\hline 4 & 0.1661 & 110.00 & $109.01 \pm 0.34$ & 99.10 \\
\hline 5 & 0.1812 & 120.00 & $119.30 \pm 0.36$ & 99.42 \\
\hline Average & \multicolumn{5}{|c}{} & 99.67 \\
\hline RSD, \% & \multicolumn{5}{|c}{0.43} \\
\hline
\end{tabular}


Table 2

Estimated data for linearity of methylparaben

\begin{tabular}{|c|c|c|c|c|}
\hline Number of solution & $\mathrm{Ci}, \mathrm{mg} / \mathrm{ml}$ & $\mathrm{Ci}, \%$ (theoretical) & $\mathrm{Si} / \mathrm{S} * 100 \%, \%$ (found) & $\mathrm{RRF}$ \\
\hline$L 1$ & 0.0893 & 80.00 & $80.47 \pm 0.31$ & 100.59 \\
\hline$L 2$ & 0.1004 & 90.00 & $90.09 \pm 0.37$ & 100.10 \\
\hline$L 3$ & 0.1116 & 100.00 & $100.00 \pm 0.29$ & 100.00 \\
\hline$L 4$ & 0.1227 & 110.00 & $109.17 \pm 0.22$ & 99.25 \\
\hline L5 & 0.1339 & 120.00 & $118.62 \pm 0.30$ & 98.85 \\
Average & & & 99.76 \\
\hline RSD, \% & & & 0.70 \\
\hline
\end{tabular}

The obtained results for linearity show that the method is linear for determined compounds. The correlation coefficient is more than 0.999 for both compounds. The relative standard deviation is within $1.0 \%$ for both analytes.

\section{Precision}

Precision characteristics involve repeatability test, system suitability, and intra-laboratory precision.

\section{System suitability}

The reference solution was injected five times. Results are given in Tables 3-5.

Table 3

\begin{tabular}{|c|c|c|c|}
\hline Area & RSD $(\%)$ & Estimated data for Benzydamine hydrochloride peak \\
Theoretical plate number & Symmetry coefficient \\
\hline 1906339 & & & 1.385 \\
\hline 1906741 & \multirow{2}{*}{0.02} & 8783 & \\
\hline 1906668 & & & \\
\hline 1905940 & & & \\
\hline
\end{tabular}

Table 4

\begin{tabular}{|c|c|c|c|} 
Area & RSD $(\%)$ & Theoretical plate number & Symmetry coefficient \\
\hline 13944562 & & & 1.101 \\
\hline 13956871 & \multirow{2}{*}{0.07} & 7699 & \\
\hline 13962528 & & & \\
\hline 13953774 & & & \\
\hline 13958145 & & & \\
\hline
\end{tabular}

Criteria for system suitability

Table 5

\begin{tabular}{|c|c|c|c|c|}
\hline \multirow{3}{*}{ Analyte } & & & & \\
\hline & Parameter & Symbol & $\begin{array}{l}\text { Obtained } \\
\text { value }\end{array}$ & $\begin{array}{l}\text { Acceptance } \\
\text { criteria }\end{array}$ \\
\hline & $\begin{array}{l}\text { The number of theoretical plates from the reference solution } \\
\text { chromatogram }\end{array}$ & NTP & 8783 & $\leq 2000$ \\
\hline \multirow{2}{*}{$\begin{array}{l}\text { Benzydamine } \\
\text { hydrochloride }\end{array}$} & Symmetry coefficient for Benzydamine hydrochloride peak & TF & 1.385 & $\leq 2.0$ \\
\hline & $\begin{array}{l}\text { The relative standard deviation for peak area of Benzyda- } \\
\text { mine hydrochloride from reference solution RS chromato- } \\
\text { grams, } \%\end{array}$ & RSD & 0.02 & \\
\hline \multirow{2}{*}{$\begin{array}{l}\text { Methyl para- } \\
\text { ben }\end{array}$} & Symmetry coefficient for methylparaben peak & TF & 1.107 & $\leq 2.0$ \\
\hline & $\begin{array}{l}\text { The relative standard deviation for peak area of methylpara- } \\
\text { ben from reference solution RS chromatograms, \% }\end{array}$ & RSD & 0.07 & $\leq 1.0 \%$ \\
\hline
\end{tabular}

\section{Repeatability}

Repeatability was assessed, injecting five times each of six parallel solutions, prepared from the model sample of the drug product and one reference solution (Table 6).

Table 6

\begin{tabular}{|c|c|c|c|c|}
\hline \multicolumn{2}{|c|}{ Results for repeatability of the chromatographic system } \\
Parameter & Symbol & Analyte & $\begin{array}{c}\text { Obtained } \\
\text { value }\end{array}$ & $\begin{array}{c}\text { Acceptance } \\
\text { criteria }\end{array}$ \\
\hline $\begin{array}{c}\text { The relative standard deviation for five } \\
\text { measurements } \%\end{array}$ & RSD & $\begin{array}{c}\text { Benzydamine hydro- } \\
\text { chloride }\end{array}$ & 1.04 & $\leq 1.4$ \\
\cline { 3 - 5 } & & Methylparaben & 1.08 & $\leq 2.8$ \\
\hline
\end{tabular}




\section{Intermediate precision}

Intermediate precision was studied for two days. Two different analysts prepared one reference solution and three test solutions on different days. The solutions were injected in triplicate. Results are given in Table 7.

Table 7

Results of intermediate precision study

\begin{tabular}{|c|c|c|c|}
\hline Analyte & $\begin{array}{c}\text { Parameter } \\
\text { The relative standard deviation, RSD \% }\end{array}$ & $\begin{array}{c}\text { Obtained value } \\
1.22 \\
\end{array}$ & $\begin{array}{c}\text { Acceptance criteria } \\
\leq 2.0\end{array}$ \\
\hline Benzydamine hydrochloride & Difference between obtained results, $\Delta, \%$ & $\begin{array}{c}\text { By analysts }-1.01 \\
\text { By days }-0.99\end{array}$ & $\leq 2.3$ \\
\hline \multirow[b]{2}{*}{ Methylparaben } & Relative standard deviation, RSD \% & 1.28 & $\leq 4.0$ \\
\hline & Difference between obtained results, $\Delta, \%$ & $\begin{array}{c}\text { By analysts }-1.01 \\
\text { By days }-0.99\end{array}$ & $\leq 4.5$ \\
\hline
\end{tabular}

Obtained data demonstrate sufficient precision for both compounds within the rage of acceptance criteria. The biggest relative standard deviation was observed in intermediate precision test and was 1.22 for Benzydamine hydrochloride and 1.28 for Methylparabene. System suitability is within the acceptance range with regard to theoretical number plates, variation coefficient and peak symmetry for both compounds.

\section{Accuracy}

Accuracy was estimated using nine model solutions for Benzydamine hydrochloride and Methylparaben, respectively.

Solutions with the known concentration of determined analytes were injected five times each. Results for accuracy are given in Table 8 .

Table 8

Results of accuracy

\begin{tabular}{|l|l|c|c|}
\hline \multicolumn{1}{|c|}{ Analyte } & \multicolumn{1}{|c|}{ Parameter } & Obtained value & Acceptance criteria \\
\hline \multirow{2}{*}{ Benzydamine hydrochloride } & Recovery, Z \% & 97.78 & $97-103$ \\
\cline { 2 - 4 } & Relative standard deviation by Z, RSD \% & 0.46 & $\leq 3$ \\
\hline \multirow{2}{*}{ Methyl paraben } & Recovery, Z \% & 100.07 & $95-105$ \\
\cline { 2 - 4 } & Relative standard deviation by Z, RSD \% & 1.22 & $\leq 5$ \\
\hline
\end{tabular}

The recovery for Benzydamine hydrochloride and Methylparabene was 97.78 and 100.07 respectively. The RSD Benzydamine hydrochloride was 0.46 ; RSD for methylparabene was 1.22. Obtained results indicate the satisfactory accuracy of the method.

\section{Robustness}

Robustness of the method was shown by studying the reliability of the chromatographic procedure and stability of test solutions.
Stability of solutions was studied by injecting the same solutions with a difference of 24 and 48 hours. Results of the stability of solution study are given in Table 9.

Reliability of chromatographic procedure was assessed by variation of flow rate, $\mathrm{pH}$ of the mobile phase. Results of reliability study are given in Tables 10, 11.

Table 9

Stability of solution results

\begin{tabular}{|c|c|c|c|}
\hline Time of storage & 0 hours & \multicolumn{2}{c|}{$\begin{array}{c}\text { 24 hours } \\
\text { Benzydamine hydrochloride }\end{array}$} \\
\hline $\begin{array}{c}\text { The difference between peak areas relative to 0 hours } \\
\text { point of reference solution, \% }\end{array}$ & - & 1.68 & 3.70 \\
\hline $\begin{array}{c}\text { The difference between peak areas relative to 0 hours } \\
\text { point of test solution, \% }\end{array}$ & - & 0.22 & 0.63 \\
\hline $\begin{array}{c}\text { The difference between peak areas relative to 0 hours } \\
\text { point of reference solution, \% }\end{array}$ & - & 1.67 & 3.63 \\
\hline $\begin{array}{c}\text { The difference between peak areas relative to 0 hours } \\
\text { point of test solution, \% }\end{array}$ & - & 0.24 & 0.69 \\
\hline
\end{tabular}

Table 10

Results of flow rate influence

\begin{tabular}{|c|c|c|}
\hline $\begin{array}{c}\text { Flow rate, } \\
\mathrm{ml} / \mathrm{min}\end{array}$ & $\begin{array}{c}\text { Difference between Benzydamine hydrochloride } \\
\text { peak areas S(TS)/S(RS) relative to set condi- } \\
\text { tionsons, } \%\end{array}$ & $\begin{array}{c}\text { Difference between Methylparaben peak } \\
\text { areas S(TS)/S(RS) relative to set condi- } \\
\text { tionsons, } \%\end{array}$ \\
\hline 1.0 & - & - \\
\hline 0.9 & 0.19 & 0.15 \\
\hline 1.1 & 0.28 & 0.20 \\
\hline
\end{tabular}


Results of $\mathrm{pH}$ influence

\begin{tabular}{|c|c|c|}
\hline $\begin{array}{c}\text { Mobile } \\
\text { phase }\end{array}$ & $\begin{array}{c}\text { Difference between Benzydamine hydrochloride peak } \\
\text { areas S(TS)/S(RS) relative to set conditionsons, \% }\end{array}$ & $\begin{array}{c}\text { Difference between Methylparaben peak areas } \\
\text { S(TS)/S(RS) relative to set conditionsons, \% }\end{array}$ \\
\hline pH 3.0 & - & - \\
\hline pH 2.0 & 0.46 & 0.37 \\
\hline pH 4.0 & 0.72 & 1.10 \\
\hline
\end{tabular}

Robustness of the method demonstrates that the results of the method are reliable and unaffected despite a minor variation of the method parameters.

The robustness of the method was shown on a variation of chromatographic parameters, such as: $\mathrm{pH}$ variation in the range \pm 1.0 ; flow rate variation in the range $\pm 10 \%$; analysis time delay 24 and 48 hours.

Obtained data demonstrate the sufficient robustness of analytical procedure.

Thus, results of validation indicate that the developed method is fit for its purpose, and can be used for simultaneous estimation of Benzydamine hydrochloride and methylparaben.

\section{Discussion}

The developed HPLC analytical method is fast, specific, robust, accurate and linear. It was shown that the method is linear in the range of $80-120 \%$ of analyte concentrations with the RSD of 1.04 and 1.08 , respectively. The linearity coefficient for each compound was more than 0.999 .

The method is accurate in with recovery in range of $98 \%-102 \%$. Robustness of the method indicated that minor changes of the method nor environment would not influence on performance of the procedure.

In previous researches, benzydamine hydrochloride and methylparaben were separately determined that caused a consumption of time and equipment resources of analytical staff in quality control laboratory. Contemporary approach of "Green chemistry" was successfully applied for simultaneous analysis of two compounds in the formulation with one chromatographic run.

In the current study diode array detector was used for detection of analytical signal. It allowed performing detection at different wavelength as benzydamine and methylparaben have different absorption maximum.

Grace Altima C18 column with $5 \mu \mathrm{m}$ particle size was used for successful separation with an overall time of one injection less than 10 minutes.

Study limitations. Current approach might have some restrictions, as the utilization of an expensive analytical equipment and standards might be an issue for laboratories, although, the method that was developed is rigid and its performance will not be affected by slight changes in the environment of method parameters.

Prospects for further research. Considering the perspectives of the current research, the further immersion to the "Green Chemistry" approach may be implemented by using UHPLC or consideration of selection a gas chromatography as an alternative analytical method.

\section{Conclusions}

This paper describes the development of the analytical method for simultaneous determination of Benzydamine hydrochloride and methylparaben in a spray dosage form of Benzydamine hydrochloride by HPLC. Developed method demonstrates modern approach of "Green analytical chemistry", as it is rapid, reliable, and does not require specific or toxic chemicals. The method demonstrates high precision, sufficient sensitivity and resolution. Validation of the developed procedure was carried out. The method was successfully applied in routine analysis in quality control laboratories for simultaneous determination of Benzydamine hydrochloride and methylparaben.

\section{Conflict of interest}

The authors declare that they have no conflicts of interest.

\section{References}

1. Turnbull, R. S. (1995). Benzydamine Hydrochloride (Tantum) in the management of oral inflammatory conditions. Journal of the Canadian Dental Association, 61 (2), 127-134.

2. British pharmacopoeia. Vol. 1 (2018). London: Medicines and Healthcare products Regulatory Agency, 265.

3. British pharmacopoeia. Vol. 3 (2018). London: Medicines and Healthcare products Regulatory Agency, 181.

4. Dogan, A., E. Basc1, N. (2011). Development and Validation of RP-HPLC and Ultraviolet Spectrophotometric Methods of Analysis for the Quantitative Determination of Chlorhexidine Gluconate and Benzydamine Hydrochloride in Pharmaceutical Dosage Forms. Current Pharmaceutical Analysis, 7 (3), 167-175. doi: http://doi.org/10.2174/157341211796353228

5. Catanese, B., Lagana, A., Marino, A., Picollo, R., Rotatori, M. (1986). HPLC determination of benzydamine and its metabolite N-oxide in plasma following oral administration or topical application in man, using fluorimetric detection. Pharmacological Research Communications, 18 (4), 385-403. doi: http://doi.org/10.1016/0031-6989(86)90091-3

6. Benson, H. A. E., McElnay, J. C. (1987). High-performance liquid chromatography assay for the measurement of benzydamine hydrochloride in topical pharmaceutical preparations. Journal of Chromatography A, 394 (2), 394-399. doi: http://doi.org/10.1016/s0021-9673(01)94193-7

7. Shabir, G. (2010). A new validated HPLC method for the simultaneous determination of 2-phenoxyethanol, methylparaben, ethylparaben and propylparaben in a pharmaceutical gel. Indian Journal of Pharmaceutical Sciences, 72 (4), 421-425. doi: http://doi.org/10.4103/0250-474x.73906

8. M. Kashid, R., G. Singh, S., Singh, S. (2011). Simultaneous Determination of Preservatives (Methyl Paraben and Propyl Paraben) in Sucralfate Suspension Using High Performance Liquid Chromatography. E-Journal of Chemistry, 8 (1), 340-346. doi: http://doi.org/10.1155/2011/360431 
9. Turabi, Z. M., Khatatbeh, O. A., Al-Abed, D. N. (2014). RP-HPLC Method Development and Validation for the Simultaneous Determination of Mebendazole and the Two Preservatives Methylparaben and Propylparaben in Pharmaceutical Oral Suspension Dosage Form. International Journal of Pharmaceutical Sciences and Drug Research, 6 (1), 70-74.

10. Koel, M., Kaljurand, M. (2006). Application of the principles of green chemistry in analytical chemistry. Pure and Applied Chemistry, 78 (11), 1993-2002. doi: http://doi.org/10.1351/pac200678111993

11. He, Y., Tang, L., Wu, X., Hou, X., Lee, Y. (2007). Spectroscopy: The Best Way Toward Green Analytical Chemistry? Applied Spectroscopy Reviews, 42 (2), 119-138. doi: http://doi.org/10.1080/05704920601184259

12. Płotka-Wasylka, J., Gałuszka, A., Namieśnik, J.; Płotka-Wasylka, J., Namieśnik, J. (Eds.) (2019). Green Analytical Chemistry: Summary of Existing Knowledge and Future Trends. Green Analytical Chemistry. Green Chemistry and Sustainable Technology. Singapore: Springer, 431-449. doi: http://doi.org/10.1007/978-981-13-9105-7_15

13. Bhandari, M., Raj, S. (2017). Practical approach to green chemistry. International Journal of Pharmacy and Pharmaceutical Sciences, 9 (4), 10-26. doi: http://doi.org/10.22159/ijpps.2017v9i4.15640

14. Validation of analytical procedures Q2 R1 (2005). International Conference on Harmonization. Available at: https://database.ich.org/sites/default/files/Q2_R1_Guideline.pdf

15. Eldin, A., Ismaiel, O., Hassan, W., Shalaby, A. (2015). Development and validation of stability indicating green HPLCUV method for determination of Cephalexin in pharmaceutical dosage forms and human urine using micellar mobile phase. International Journal of Pharmacy and Pharmaceutical Sciences, 7 (9), 122-127. Available at: https://innovareacademics.in/journals/ index.php/ijpps/article/view/5950

16. United States Pharmacopeial Convention. General chapter: Validation of compendial procedures. Rockville: United States Pharmacopeial Convention.

17. Kozakevich, Y., Lobrutto, R. (2007). HPLC for pharmaceutical scientists. New Jersey: John Wiley and Sons. doi: http://doi.org/10.1002/0470087951

18. Grossman, R. B., Finkel, R. (2017). ACE and JChem acidity and basicity calculator, ACE UKY-4.2 \& Marvin JS by ChemAxon: Perfluorononane-sulfonic acid. Lexington: University of Kentucky \& Pearson Education.

19. Weast, R. C. (1985-1986). Handbook of Chemistry and Physics. Florida: CRC Press Inc.

20. LoBrutto, R. (2000). Retention of Ionizable Compounds in HPLC. Available at: https://scholarship.shu.edu/dissertations/1240

Received date 01.06.2020

Accepted date 24.06.2020

Published date 30.06.2020

Vasyl Chornyi, Head of Laboratory, Liquid Drug Development Laboratory, SC «Farmak», Kirilivska str., 63, Kyiv, Ukraine, 04080

E-mail: vasylcherniy@gmail.com

Olga Chorna, PhD, Assistant, Department of Clinical Biochemistry, Toxicology and Pharmacy, Kharkiv Medical Academy of Postgraduate Education, Amosova str., 58, Kharkiv, Ukraine, 61176

E-mail: ovchorna@i.ua

Victoriya Georgiyants, Doctor of Pharmaceutical Sciences, Professor, Head of Department, Department of Pharmaceutical Chemistry, National University of Pharmacy, Pushkinska str., 53, Kharkiv, Ukraine, 61002

E-mail: vgeor@nuph.edu.ua 